\title{
Целине - 65, и 25 лет ё̈ комплексной оценке: обратимость экологических последствий при малой обратимости идеологических
}

\section{The 65-anniversary of the virgin lands campaign, and the 25-anniversary of its comprehensive assessment: reversibility of environmental consequences under poor reversibility of ideological ones}

\author{
Левыкин С. В., Казачков Г. В., Семёнов Е. А. \\ Levykin S. V., Kazachkov G. V., Semyonov Ye. A. \\ Институт степи УрО РАН, г. Оренбург, Россия. E-mail: stepevedy@yandex.ru \\ Institute of Steppe of the Urals Branch of RAS, Orenburg, Russia
}

\begin{abstract}
Реферат. К 25-летнему юбилею комплексной оценки итогов и уроков целины обоснована, вопреки ранее данным прогнозам, обратимость экологических последствий и малая обратимость идеологических установок. Приводится ряд новых фактов в подтверждение комплексного характера целинного проекта и его оценок с позиций степеведения.
\end{abstract}

Ключевые слова. Вторичная степь, неоцелинная кампания, постцелинное пространство, самовосстановление степей, целина.

Summary. The reversibility of environmental consequences of the virgin lands campaign and poor reversibility of its ideological default settings are substantiated contrary to earlier forecasts and to 25 -anniversary of comprehensive assessment of this campaign.

Key words. Secondary steppe, steppe self-restoration, virgin land campaign, virgin land campaign area, virgin land neocampaign.

Для нас тема целины была и остаётся приоритетной, т. к. масштабы, сроки распашки степей беспрецедентны, а последствия уникальны. Предстоящий 65-летний юбилей начала кампании совпадает с 25-летием комплексных оценок в постсоветских условиях (40 лет освоению ..., 1994). Приняв активное участие в этих обсуждениях в 1994 г., мы в течение всех последующих пятилетий углубляли изучение этой проблемы, находя новые факты и аргументы и констатируя новые, порой необычайные последствия этого глобального эксперимента. К 60-летнему юбилею этого события нам стало совершенно понятно, что это был далеко не чисто аграрный, а комплексный проект (Вопросы степеведения, 2014; Левыкин и др., 2015а, 2015б; Левыкин и др., 2018).

Целинная кампания 1950-х подтвердила действие географической закономерности, установленной П. П. Семёновым-Тян-Шанским во второй половине XIX в.: при освоении новых земель изначально максимум усилий прилагается к вовлечению в активное использование, прежде всего, земельных, биологических ресурсов и полезных ископаемых, и только с признаками экологических проблем развивается потребность в сохранении и восстановлении природы (Чернявский, 1955; Chibilev, Levykin, 2013).

Нам посчастливилось изучить состояние степей от их исторического минимума, обусловленного ландшафтными последствиями целины начала 1990-х гг. до их постсоветского исторического максимума 2012-2014 гг. На сегодня нами сделан принципиально новый вывод по оценке основных последствий целинной кампании: тяжёлые экологические последствия оказались сенсационно обратимыми, в то же время идеологические и политические установки степного землепользования остались мало обратимыми. Предыдущие научные прогнозы оправдались наоборот: предполагалось, что постсовет- 
ское общество будет предпринимать масштабные усилия и вкладывать значительные ресурсы в восстановление сенокосно-пастбищных угодий на бывшем целинном пространстве, чего не произошло. Даже полностью восстановленные степные экосистемы с богатым набором краснокнижных видов продолжают восприниматься в основном как пустующие земли, на государственном уровне всячески стимулируется их распашка При этом предполагалось, что восстановить ресурсы титульных степных биологических видов едва ли удастся, что они останутся главным образом в пределах ООПТ, в то время как в действительности степные экосистемы проявили поразительную способность к регенерации, всего за 10-15 лет восстановив свой экосистемный базис на сотнях тысяч гектаров. Быстрому восстановлению способствовала высокая генеративная активность титульных степных растений, которая проявилась не столько у вековой целины, сколько у молодых травостоев, развивающихся и захватывающих жизненное пространство (Левыкин и др., 2014; Левыкин и др., 2017).

Сегодня, в разгар неоцелинной кампании, когда ужесточены требования к целевому использованию степных сельхозугодий, можно ожидать перепашку не только бурьянов, но и едва сформировавшихся вторичных степей. В связи с неизбежностью новой перепашки на постцелинном пространстве и отсутствием сопоставимых проявлений потенциала самовосстановления к западу от него возникает принципиальный вопрос: сможет ли потенциал самовосстановления степей сохраниться после новой тотальной подсолнечниково-пшеничной распашки? Тот факт, что к западу от постцелинного пространства восстановительный потенциал степей уже далеко не столь заметен, а так же малопредсказуемые климатические изменения обязывают нас допустить, что ещё один неоцелинный натиск степи могут уже не выдержать.

От юбилея к юбилею, по мере накопления новых фактов и сведений, мы принципиальным образом смягчили прежде негативную оценку основных уроков, итогов и последствий целины. Ещё раз подчеркнём, что это оказался комплексный проект, лишь выглядящий авантюрой с узких аграрных позиций. Целина решала множество стратегических задач, в т.ч. оборонных. В комплексных оценках этого проекта мы не можем оставить без внимания ставшие в последние годы общедоступными сведения об одновременной переброске техники и ресурсов на экстренное строительство космодрома, поток которой не сильно выделялся в потоке грузов на целину (Левыкин и др., 2015a). С экологических позиций, с учётом выявленного нами потенциала самовосстановления степей, мы пришли к признанию уникального значения целинного проекта как крупнейшего в мире практического эксперимента по массовому омоложению степных травостоев, своего рода перезагрузке степных экосистем. По научной значимости такой эксперимент сопоставим с результатами, полученными на Большом адронном коллайдере. Надеемся, что в ближайшем будущем результаты этого эксперимента, изучавшие нами и нашими коллегами, будут более востребованными.

К очередному юбилею целины добавим несколько фактов в пользу её оценки, формирующейся с позиций современного степеведения: в 2015 г. получены новые подтверждения космической составляющей целинного проекта (Кара, 2015); актуализировано интервью Н. С. Хрущёва газете «Нью Йорк Таймс» от 23.02.1964 г., в котором он сообщил, что бывшие целинные земли, подвергшиеся засухе и эрозии, выполнив свою миссию в трудный период развития СССР, будут переведены в пастбищные угодья, а усилия по интенсификации земледелия будут направлены в более благоприятные староосвоенные регионы (Einaudi, 1964). Возможно, развитие целинных регионов, начиная с посевной 1965 г., было бы совсем иным не будь Н. С. Хрущёв отстранён от власти в октябре 1964 г. Но следующим руководителем стал Л. И. Брежнев, который считал организацию распашки целины в Казахстане и особенно большой урожай 1956 г. одним из своих главных успехов. Поэтому сама постановка вопроса о структурных изменениях землепользования на целине стала невозможной на весь период его правления. Также изучен примечательный факт, хотя и не имеющий прямого отношения к агроэкологии, но весьма символичный для комплексной оценки проекта. Это неоднозначная роль Ж. Ташенева, который будучи секретарём Актюбинского обкома КПСС, изначально активно поддерживал целинный проект со стороны Казахстана, а по одной из версий, даже был одним из его инициаторов, но впоследствии, когда в середине 1960-х гг. на высшем уровне решался вопрос об управлении вновь учреждённым на севере Казахстана Целинным краем, он выступил категорически против, сумел аргументированно отстоять целостность Казахстана и стал национальным героем современного Казахстана (Долгополов, 2010; Жумабек Ташенев..., 2015). 
В очередной юбилейный год целины как никогда ранее необходим здравый анализ событий на основе объективной информации с учётом полученных новых знаний и запросов нового времени, нацеленный на научно-теоретическое обеспечение комплексного обустройства постцелинного пространства, возможно в формате национального проекта. Мы готовы к конструктивному взаимодействию со всеми научными, административными и хозяйственными структурами, готовыми предпринимать систематические усилия по наведению агроэкологического порядка в степной зоне.

Благодарности. Работа выполнена по теме НИР ИС УрО РАН №ГР АААА-А17-117012610022-5.

\section{ЛИТЕРАТУРА}

40 лет освоению целинных и залежных земель Оренбургской области (1954-1993). - Оренбург: Оренб. обл. упр-е статистики, 1994. -78 с.

Вопросы степеведения. - Оренбург: ИС УрО РАН, 2014. - Вып.11. - 117 с.

Долгополов А. Б. Избранные лекции по Истории Казахстана.-- Караганда. - 2010. - С. 82.

Жумабек Ташенев. Пример неутомимого служения родине // Портал «История Казахстана». 24.02.2015. URL: https://e-history.kz/ru/publications/view/984 (Дата обращения: 12.03.2019).

Kapa Ю. B. Главный (Главный конструктор) [фильм, биографическая драма]. - студия «Мастер» при финансовой поддержке Министерства культуры РФ и поддержке OAO РЖД, 2015. - 20-я минута. URL: http://www. tvroscosmos.ru/5632/ (Дата обращения: 12.03.2019).

Левыкин С. В., Семёнов Е. А., Чибилёв А. А. (мл), Петрищев В. П. Проблемы землепользования и пространственного развития степных регионов : монография. - М.: РУСАЙНС, 2018. -216 с.

Левыкин С. В. Казачков Г. В. Чибилёва В. П. Современная парадигма целины: распашка новых степей или агровозрождение Нечерноземья? Оценка с позиций конструктивной модели степи // Проблемы региональной экологии, 2015а. - № 2. - С. 170-177.

Левыкин С. В., Казачков Г. В., Чибилёва В. П. Современная парадигма целины: распашка новых степей или агровозрождение Нечерноземья? Биосферная значимость и перспективы // Проблемы региональной экологии, 2015б. - № 3. - C. 228-233.

Левыкин С. В., Казачков Г. В., Яковлев И. Г., Грудинин Д. А. Ландшафтообразующая роль ковыля Лессинга в процессе формирования вторичных степей Заволжско-Уральского региона // Известия Самарского НЦ РАН, 2014. - T.16. - №1(4). - C. 1092-1095.

Левыкин С. В., Нурушев М. Ж., Казачков Г. В., Яковлев И. Г., Грудинин Д. А. Специфика, проблемы и перспективы самовосстановления ландшафтно-биологического разнообразия степей на постцелинном пространстве Заволжско-Уральского экорегиона // Вестник Оренбургского государственного университета, 2017. - №11 (211). - C. 98-101.

Чернявский В. И. Пётр Петрович Семёнов-Тян-Шанский и его труды по географии. - М.: Гос. изд-во геогр. лит-ры, 1955. - 296 с.

Chibilev A., Levykin S. Virgin Lands Divided be an Ocean: The Fate of Grasslands in the Northern Hemisphere. Translated by David Moon // Nova Acta Leopoldina NF 114, 2013- Nr. 39. - P. 91-103.

Einaudi G. Khrushchev reported planning to give up Virgin-Land Farms // The New York Times, 1964. - February 23. - P. 2. 